\title{
ANALISIS KESULITAN BELAJAR BAHASA INGGRIS MAHASISWA
}

\author{
Oleh: \\ Ayunda Sabrina Sormin \\ Prodi Pendidikan Bahasa Inggris, FKIP UMTS \\ email: ayunda.sabrina888@gmail.com
}

\begin{abstract}
Penelitian ini menganalisis kesulitan belajar bahasa Inggris mahasiswa prodi ekonomi. Fokus penelitian ini adalah menemukan kesulitan siswa dalam menguasai kompetensi bahasa Inggris dilakukan di UMTS dengan melibatkan 50 mahasiswa. Peneliti menggunakan pendekatan klasik dan individual dalam mengumpulkan data kualitatif dan kuantitatif. Prosedur yang digunakan konteks, input, proses, dan produk / CIPP-Model Evaluasi untuk manfaatnya untuk meningkatkan kualitas pengajaran. Data dianalisis dengan menggunakan McDonough \& McDonough Model, yaitu .: (1) eksplorasi pada kedua proses belajar siswa dan hasilnya; (2) menganalisis hasil eksplorasi melalui kuesioner, wawancara dengan siswa; (3) melakukan peer-debriefing, yaitu wawancara dengan dosen lain yang terkait dengan, metode, konten silabus, apakah mereka telah sesuai dengan kebutuhan siswa. Temuan menunjukkan bahwa siswa belajar bahasa Inggris kesulitan untuk: (1) rasa dipaksa; (2) penguasaan rendah pada konsep dasar / intake; (3) kurang dukungan dari lingkungan mereka; (4) lupakan faktor; (5) memiliki lebih sedikit kesempatan untuk berlatih. Sehubungan dengan temuan tersebut, disarankan agar guru dan lembaga harus memfasilitasi dan memberikan motivasi tinggi untuk proses belajar bahasa Inggris siswa mereka.
\end{abstract}

Kata kunci: Bahasa Inggris, pembelajaran, kesulitan

PENDAHULUAN

\section{Bahasa Inggris seringkali}

menjadi "momok" bagi mahasiswa.

Alasan pertama yang paling sering

dikemukakan adalah karena bahasa

inggris bukanlah bahasa "ibu"

sehingga sulit untuk

mengucapkannya. Alasan kedua

adalah rasa malas untuk latihan listening , reading, writing dan speaking sehingga semakin menjadikan bahasa inggris sulit dipahami. Alasan yang kedua inilah yang seharusnya menjadi bekal bagaimana membelajarkan bahasa inggris dikelas. Namun, beberapa dosen seringkali lupa menyajikan "kebutuhan" bahasa inggris sesuai dengan jurusan mahasiswanya. 
Mata kuliah bahasa Inggris di perguruan tinggi di Indonesia umumnya dikelompokan ke dalam Mata kuliah Pengembangan Kepribadian (MPK) yang wajib diikuti oleh mahasiswa. Tujuan mata kuliah ini adalah untuk membekali para mahasiswa ketrampilan berkomunikasi aktif dalam bahasa Inggris yaitu kemampuan mendengar (listening), berbicara (speaking), membaca (reading) dan menulis (writing). Sebagai mata kuliah wajib, bahasa Inggris disampaikan dalam bentuk mata kuliah umum dimana metode penyampaiannya berupa ceramah, diskusi, kerja kelompok dan praktik berbahasa secara langsung.

Pengajaran bahasa Inggris( language teaching) berdasarkan kebutuhan dan minat mahasiswa secara umum dikelompokan menjadi dua yaitu bahasa Inggris umum (General English) dan Bahasa Inggris khusus (English for Specific Purposes ). General English mempelajari tentang tata bahasa (fundamental of grammar), sedangkan ESP mempelajari bahasa Inggris berdasarkan pada profesi pekerjaan atau kebutuhan tertentu mahasiswa misalnya ekonomi, agama, biologi, pendidikan, sosial dan kesehatan.

Pembelajaran mata kuliah bahasa Inggris pada Mahasiswa Jurusan Ekonomi , Universitas Muhammadiyah Tapanuli Selatan selama ini berisi tentang materi umum bahasa Inggris (general English). Materi diambil dari buku atau text book bahasa Inggris terbitan dari dalam dan luar negeri . Topik atau tema dalam buku teks kebanyakan tentang hal-hal yang sifatnya grammar (tata bahasa). Sebagai contoh topik atau tema yang sangat umum yang berhubungan dengan pengetahuan kebahasaan (linguistic knowledge) seperti; introduction,article, subject pronouns, present tense, possessive adjective, singular-plural, to be: yes/no questions short answers, adjectives, possessive nouns, dan prepositions. Materi tersebut haruslah dihubungkan dengan jurusan mahasiswa atau yang kita kenal dengan ESP ( English For Special Purpose). Namun belum semua dosen mampu menjawab tantangan belajar bahasa inggris terkini ini. Sehingga masih saja mahasiswa merasa kesulitan belajar bahasa inggris ( BI) dan pada 
akhirnya tidak mampu menjawab permintaan dunia kerja .

Hasil pengamatan awal menunjukkan bahwa modal awal (intakes) BI mereka amat rendah. Padahal, kualitas input tentu akan mempengaruhi baik proses maupun hasil belajarnya. Kualitas intakes PT merupakan output dari jenjang pendidikan di sekolah menengah.

Selain itu, frekuensi pembelajaran diperguruan tinggi juga kurang mendukung peningkatan kualitas pembelajaran BI. BI umumnya hanya diberikan di semester 2, dengan frekuensi 2 Satuan Kredit Semester (SKS) per-minggu. Waktu pembelajaran BI relatif kurang proporsional dengan kebutuhan mahasiswa, apalagi BI merupakan salah satu kunci untuk mengatasi berbagai persoalan lulusan di masa depan, yang semakin keras persaingannya. Penguasaan BI juga merupakan sarana guna mendongkrak sumber daya manusia Indonesia, yang menurut Human Development Index termasuk kategori paling rendah di Asia.
Persaingan global di segala bidang menuntut peningkatan kualitas sumber daya manusia (SDM) termasuk dosen, sebagai ujung tombaknya. Output perguruan tinggi (PT) harus benar-benar berkualitas agar berdaya saing dan memiliki posisi tawar tinggi. Salah satu upaya untuk mewujudkan hal tersebut di atas adalah dengan meningkatkan kualitas pembelajaran BI. Penguasaan BI akan membuka wawasan mereka terhadap perkembangan ilmu pengetahuan dan teknologi, termasuk pendidikan yang saat ini dapat diakses dengan mudah dari berbagai sumber.

Peningkatan mutu pembelajaran BI dapat tercapai jika diketahui latar belakang kesulitan belajarnya. Informasi tentang kesulitan belajar dapat digunakan sebagai dasar penentuan tujuan, metoda, strategi, dan materi pembelajaran yang relevan dengan kebutuhan lulusan. Untuk itu , diperlukan kajian mengenai latar belakang kesulitan belajar BI agar tidak lagi menjadi "momok". Penelitian ini melibatkan mahasiswa Prodi Ilmu Pendidikan Ekonomi Universitas Muhammadiyah Tapanuli Selatan. 


Berdasarkan observasi yang
dilakukan penulis pada awal
semester, terdapat indikasi kualitas
penguasaan BI yang rendah.
Sebagian besar ekspresi dan instruksi
dosen dengan menggunakan BI
paling dasar pun sulit dipahami
oleh sebagian besar mahasiswa,
termasuk kesulitan dalam
pengembangan kompetensi
ketrampilan berbahasa membaca,
menyimak, berbicara, dan
menulis pada taraf dasar (elementary
level). Padahal, mereka telah
mempelajari BI selama enam
semester di sekolah menengah.
Berdasarkan fenomena inilah penulis
menganalisis kesulitan belajar BI
mahasiswa, yang selanjutnya dapat
dijadikan sebagai bahan peningkatan
mutu belajar.

Kesulitan belajar didasari oleh: (1) motivasi belajar; (2) intakes BI, (3) peranan dosen dan mahasiswa dalam pembelajaran, (4) sarana prasarana, (5) materi pembelajaran, dan (6) lingkungan belajar. Keenam ranah inilah yang merupakan variabel kajian penelitian. Sebagai basis kajian, penulis merujuk beberapa teori dan hasil penelitian terdahulu yang relevan. Acuan teoretisnya menyangkut berbagai konsep tentang motivasi belajar, pembelajaran $\mathrm{BI}$, peranan dosen dan mahasiswa dalam pembelajaran, sarana/prasarana pembelajaran BI terstandar, materi pembelajaran, dan lingkungan belajar yang ideal.

Motivasi ada dua jenis, yaitu intrinsik dan ekstrinsik. Motivasi intrinsik adalah suatu dorongan untuk melakukan sesuatu tanpa paksaan (reinforcement) dan hadiah (rewards) dari siapapun. Motivasi ekstrinsik adalah dorongan untuk melakukan sesuatu tergantung pada rewards. Jika seseorang menyadari dirinya memiliki motivasi intrinsik, hadiah dapat mengakibatkan pengaruh negatif pada performansinya (Gage \& Berliner, 1984: 412-441).

Pembelajaran (learning) adalah proses sadar yang melibatkan memori seseorang terkait dengan informasi yang sedang dipelajari, misalnya mengucapkan salam, menggunakan kaidah-kaidah bahasa, dan kosakata (Tomlinson, 1998: 4). Pembelajaran bahasa dapat berupa pengetahuan tentang sistem bahasa (language usage) dan penggunaan bahasa (language use). Pembelajaran bahasa 
modern melibatkan lembaga, pengajar, pembelajar, dan pengajaran (Richards, 2001b: 198) serta mengutamakan

pengalaman

belajar, penghargaan diri (selfesteem), keterlibatan emosional, keterhubungan pembelajaran dengan daya pikir, (representasi daya pikir melalui pendayagunaan indera penglihatan, asosiasi emosional, dan penggunaan daya suara dalam), penggunaan bahasa secara komunikatif, dan materi pembelajaran yang mendorong kreativitas pembelajar (Tomlinson \& Masuhara, 2004: 2-3).

Sistem pembelajaran bahasa modern idealnya berbasis analisis kebutuhan (AK). AK merupakan prosedur pengumpulan informasi tentang kebutuhan pembelajaran pada tataran pembelajar tertentu, yaitu untuk merumuskan tujuan dan muatan pembelajaran (Richards, 2001b: 51-90; Gall, 2003: 557). Pada level perguruan tinggi, AK berfokus pada penguasaan keterampilan berbahasa sesuai dengan bidang studi pembelajar. Berbagai aspek tersebut di atas melibatkan peran dosen dan mahasiswa.
Dosen memiliki peran yang sama terkait dengan asumsi tentang bahasa dan pembelajaran bahasa pada level pendekatannya (Cunningsworth, 1995: 113; Richards\& Rodgers, 2001: 27-29). Mayoritas penerapan metode tergantung sepenuhnya kepada dosen sebagai sumber pengetahuan dan pengarahan, katalisator, konsultan

pembimbing, dan model pembelajaran dan pengembang pola-pola interaksional antara dosen dan mahasiswa. Sistem perancangan pengajaran sangat dipengaruhi oleh cara dosen memperlakukan mahasiswa sesuai dengan penerapan metode pembelajaran yang dipilihnya, dengan cara merefleksikan respon tersurat dan tersirat terhadap berbagai pertanyaan menyangkut kontribusi mahasiswa dalam proses pembelajaran. Hal ini dapat dilihat dari jenis aktivitas yang dilakukan, pengontrolan tingkat keberhasilan belajar, penerapan berbagai pola pengelompokan mahasiswa, tingkat pengaruh pembelajaran mahasiswa lain, dan perannya sebagai prosesor, performer, inisiator, dan problem solver. 
Proses

pembelajaran

melibatkan penyiapan materi ajar sebagai sarana untuk mewujudkan tujuan pembelajaran dan akan merefleksikan keputusan menyangkut tujuan utama pengadaan bahan ajar, yaitu menyajikan isi, mempraktikkan, memfasilitasi komunikasi antarmahasiswa, dan mendorong mahasiswa untuk belajar mandiri. Contoh materi ajar, yaitu buku teks, audiovisual, dan tayangan komputer (computer display).

\section{Pada}

metodologi

komunikatif, materi ajar berperan untuk: (1) memfasilitasi pengembangan kemampuan komunikatif mahasiswa dalam menginterpretasi, mengekspresikan bahasa, dan bernegosiasi antarmahasiswa; (2) membantu pemahaman wacana dan aktivitas berbahasa yang relevan dengan kebutuhan komunikatif antarpengguna bahasa; (3) memandu minat serta melibatkan intelegensi dan kreativitas mahasiswa; (4) melibatkan berbagai tipe teks dan media untuk pengembangan kompetensi melalui berbagai macam aktivitas dan latihan (Richards, 1995: 24-25).

Keberhasilan pengajaran bukan hanya dipengaruhi oleh kualitas dosen, melainkan juga dipengaruhi oleh eksistensi lembaga, motivasi belajar mahasiswa dan proses pengajarannya. Kondusif tidaknya lembaga, tergantung pada: tujuan dan misi lembaga; gaya kelola; sikap kebersamaan antarstaf; peran dosen; sistem monitoring; fasilitas pendukung; sistem perencanaan kurikulum dan pengajaran; kiat lembaga untuk melakukan perubahan; dan keterbukaan komunikasi. Kualitas output dan outcome tergantung pada peran mahasiswa dalam melakukan aktivitas belajarnya. Peran aktif mahasiswa tergantung pada tingkat motivasinya dalam belajar. Motivasi belajar yang tinggi akan mendukung peningkatan hasil belajar.

\section{METODE PENELITIAN}

Penelitian studi kasus tunggal (single case-study) ini melibatkan 60 mahasiswa FKIP Prodi Ekonomi Universitas Muhammadiyah Tapanuli Selatan. Studi kasus merupakan suatu strategi penelitian 
kualitatif untuk menginvestigasi suatu/berbagai kasus secara empiris terkait hubungan antara fenomena dalam konteks kehidupan nyata, manakala batas antara keduanya tidak jelas (Yin,1985: 23; McDonough \& McDonough,1997: 207-208). SK merupakan upaya untuk menjelaskan suatu/berbagai keputusan menyangkut: mengapa (why) suatu kasus terjadi dan diteliti, bagaimana implementasinya (how to implement), dan apakah hasilnya (what is/are the results).

Studi Kasus memiliki empat karakteristik, yaitu (1) studi fenomena yang bersifat kasuistik; (2) kajian mendalam menyangkut suatu/berbagai kasus; (3) kajian alamiah suatu/berbagai fenomena; dan (4) kajian perspektif emik/empiris terhadap suatu/berbagai kasus yang dihadapi partisipan penelitian (Gall, 2003: 435-436). Hasil studi kasus dalam penelitian ini selanjutnya dapat dijadikan sebagai basis peningkatan kualitas pengajaran dosen yang bersangkutan, yang bermuara pada peningkatan mutu outputs dan outcomes.
Sebagai gambaran berikut ini disajikan langkah-langkah penelitian menggunakan Model Context, Inputs, Process, Product (CIPP). Pemilihan fokus (Context) pengumpulan data kualitatif (Input) kategorisasi kasus inklusif analisa data (Process) hasil analisis validasi perumusan kebijakan pembelajaran BI (Product).

Kredibilitas (trustworthiness) hasil penelitian ini diuji melalui validitas proses pembelajaran yang senyatanya di kelas BI, tri-angulasi teori dan sumber data yang dipilih secara inklusif berdasarkan permasalahan fenomenal yang muncul pada saat proses belajar berlangsung (Gall, 2003: 591). Pengumpulan datanya menggunakan instrumen: (1) peneliti sebagai pengumpul data; (2) observasi proses belajar; (3) open questionnaire (terkait dengan intakes mahasiswa); (4) dokumen berupa hasil tes formatif, tes tengah semester, dan ujian akhir semester; (5) wawancara mendalam dengan mahasiswa, khususnya yang bermasalah dalam proses pembelajaran BI selama di PT. 
Data yang terkumpul dikategorikan sesuai dengan variabel kajian, dianalisa menggunakan content analysis model (menganalisis hasil kuesioner, wawancara, dan tes), dan divalidasi menggunakan teknik triangulasi teori, sumber data dan peerdebriefing (validasi melalui sumber yang belum pernah dikaji). Data kuesionernya berupa jawaban informants menyangkut: motivasi belajar, intakes, peranan dosen dan mahasiswa dalam pembelajaran, sarana prasarana yang tersedia, materi pembelajaran, dan lingkungan belajar mereka. Semua data disortir dan dikategorikan menjadi: (1) Lowmotivated with Low-achievement, (2) Well-motivated with Lowachievement, (3) Stabilized-progress with Stable-achievement, (4) Progressive-experience with Significant-achievement yang dikodifikasi menjadi Evenly dan Significantly Progress. Berikut ini disajikan hasil penelitian sekaligus pembahasan masing-masing variabel temuannya.

\section{HASIL DAN PEMBAHASAN}

Low-motivated with Lowachievement meliputi ekspresi jawaban enam mahasiswa, yang pada intinya sebagai berikut; (1) tidak bersungguh-sungguh belajar karena bosan dan selama belajar BI belum pernah ada dosen yang menerangkan secara jelas; (2) BI di jurusan Ekonomi terlalu minim, hanya ada 2 SKS; (3) Di Jurusan Ekonomi, minat belajar meningkat tetapi tetap belum bisa berkomunikasi; (4) sejak belajar di sekolah menengah tidak berminat belajar BI karena dosen selalu memaksa maha siswa untuk belajar BI dengan berbagai alasan, sedangkan dosen tidak memahami minat masing- masing mahasiswa; (5) BI di jurusan Ekonomi tidak berbeda dengan di SMA, membosankan, karena pada dasarnya mahasiswa belajar BI karena terpaksa;

Kategori kedua meliputi 10 orang, yaitu kelompok Wellmotivated with Low-achievement. Berikut adalah cuplikan datanya: (1) Ada mahasiswa yang sangat berminat dan senang mempelajari BI karena menurut mereka BI penting untuk 
menghadapi era globalisasi; (2) Ada mahasiswa yang termotivasi belajar BI karena selain guru di Madrasah Aliyah baik, ia mempunyai pengalaman menarik, yaitu ingin tampil di muka umum melalui lomba pidato BI di MA, meskipun belum fasih berbicara; (3) Ada mahasiswa yang menilai unjuk kerja dosen BI sudah baik, hanya masih kurang dalam memberikan latihan tenses dan pekerjaan rumah; (4) Dalam belajar BI di BK ada mahasiswa yang merasa belum ada peningkatan berarti karena selain bukan jurusannya, overloaded tugas dari mata kuliah lain, dan tidak ada teman untuk praktik di luar kelas; (5) Ada mahasiswa yang ingin bisa berbicara dalam BI tetapi menurutnya kebanyakan guru kurang jelas mengajarnya sehingga setiap pelajaran BI siswanya sering membolos (6) Ada mahasiswa yang menilai dosen BI baik, banyak humor sehingga tidak membosankan dan dalam kuliahnya secara tidak langsung sering memberi tugas-tugas dialog untuk dihafalkan, sehingga banyak menambah kosa kata; (7) Ada mahasiswa yang merasa belum ada peningkatan hasil belajar, meskipun benar-benar ingin meningkatkannya; (8) Ada mahasiswa yang sangat menyukai BI karena selain guru-guru sekolah menengah sangat mengasyikkan sehingga mudah dipahami, penguasaan BI dapat memudahkan orang dalam mencari pekerjaan; (9) Ada mahasiswa yang senang belajar BI karena selain dosennya cantik, disiplin dan humoris, ia juga pandai menerangkan. Namun demikian, ada hal yang kurang disenangi mahasiswa, yaitu jadwal kuliahnya terlalu pagi, yakni jam 8 dan dosen BI selalu datang tepat waktu, padahal mereka masih ngantuk.

Kategori Stabilized-progress with Stable-achievement meliputi 10 mahasiswa. Hampir seluruh ekspresi dalam kategori data ini mempunyai kesan dan motivasi yang baik tentang pembelajaran BI, sejak mereka duduk di bangku sekolah menengah hingga di Fakultas Ekonomi UMTS. Berikut ini adalah cuplikan persepsi mereka berkaitan dengan pengalaman belajar BI: (1) Ada mahasiswa yang sebenarnya sangat berminat belajar BI andaikata faktor pendukungnya 
benar- benar ada, guru mampu memotivasi siswa dan kreatif; (2) Ada mahasiswa yang merasa dosen BI di BK kurang tegas dan keras sehingga mahasiswa kurang termotivasi belajar; (3) Ada mahasiswa yang berpendapat bahwa peningkatan minat belajar tergantung pada kemauan dan kemampuan masing-masing orang - jika punya kemampuan, pasti ada peningkatan; (4) Di perguruan tinggi mayoritas mahasiswa sudah lupa BI untungnya menurut mereka dosen BI sangat baik karena ia mampu membimbing mereka dari awal dengan penuh kesabaran; (5) Ada mahasiswa yang mengusulkan agar frekuensi belajar BI ditambah secara proporsional; (6) Ada mahasiswa yang merasa puas dengan metode pengajaran yang digunakan oleh guru dii sekolah menengah karena selalu mendapat nilai paling rendah tujuh, meskipun tidak pernah kursus; (7) Ada mahasiswa yang menilai dosennya adalah sosok wanita karier yang patut ditiru karena kedisiplinan, keuletan dan kegigihannya dalam mengajar mahasiswa ber-intake rendah $\mathrm{BI}$.

\begin{abstract}
Kategori
Progressiveexperience with Significantachievement meliputi 27 mahasiswa. Kelompok ini memiliki kesamaan persepsi tentang pengalaman belajar BI, sejak di bangku sekolah menengah hingga perguruan tinggi. Kesamaan persepsi mereka adalah, tentang kekurang- puasan belajar BI pada saat di bangku sekolah menengah. Padahal, sebenarnya mereka memiliki motivasi yang tinggi dalam mempelajari BI. Kategori data ini dikodifikasi menjadi 2 kategori, yaitu peningkatan motivasi dan hasil belajar secara bertahap (Evenly Progress) dan peningkatan motivasi dan hasil belajar secara drastis (Significantly Progress). Berikut ini disajikan cuplikan data masingmasing Kategori.
\end{abstract}

Kategori Evenly Progress: (1) Dua mahasiswa menyatakan bahwa mereka baru mulai tertarik BI di SMA karena cara mengajar guru menarik, yaitu dalam bentuk latihan, menghafal dialog di depan kelas, serta tidak pilih kasih dalam memberi latihan, tidak seperti guru-guru SLTP yang selalu menyuruh siswa menerjemahkan BI ke dalam bahasa Indonesia 
sehingga mereka merasa bosan; (2) Ada mahasiswa yang merasa bosan belajar BI di SLTP dan SMA karena guru seringkali memberikan tes mendadak; (3) Rata-rata mahasiswa kelompok merasa lebih termotivasi saat belajar BI di PT terutama ketika mereka diminta praktik di depan kelas dan merasa gugup namun pada akhirnya mereka dapat melakukannya dengan baik karena dalam berekspresi dipandu oleh dosen; (4) Rata-rata mahasiswa menyatakan bahwa dosen BI sering memberikan semangat pada mahasiswa untuk giat berlatih dan belajar; (5) Meskipun merasa kurang menguasai kosakata dan tenses, rata-rata mahasiswa menyatakan mengalami peningkatan belajar setelah di PT; (6) Rata-rata mahasiswa menyatakan, bahwa dosennya bagus, penyabar dan cara menerangkannya jelas; (7) Semua mahasiswa menyatakan bahwa belajar BI di PT ada peningkatan sehingga mereka merasa termotivasi untuk terus belajar BI.

\section{Kategori Significantly Progress}

meliputi 8 kategori ekspresi dari sejumlah 13 mahasiswa. Berikut disajikan temuan datanya: (1) Ada mahasiswa yang menyatakan bahwa guru BI-nya di sekolah menengah ada yang rajin dan pandai, tapi ada

yang malas, jarang masuk dan tidak pernah memberi ulangan harian; (2) Rata-rata mahasiswa menyatakan bahwa dosen BI di UMTS sangat baik sehingga mampu menyadarkan mereka akan pentingnya belajar $\mathrm{BI}$, bagi masa depan mereka; (3) Ratarata mahasiswa menyatakan sejak belajar BI di PT minat belajar mereka sangat meningkat, meskipun belum dapat mencapai target nilai ideal; (4) Rata-rata mahasiswa menyatakan sangat tertarik belajar BI sejak di perguruan tinggi, karena cara dosen membawakan materi sangat jelas, proses belajarnya tidak membosankan, belajarnya tidak hanya teori saja, melainkan praktik langsung misalnya dengan berbicara monolog dan dialog di depan kelas; (5) Ada mahasiswa yang menyatakan bahwa pada waktu mempelajari BI di SLTP t ia idak berminat karena sulit dan nilainya pun tidak pernah bagus namun setelah di SMA dan di UAD ia sungguh berminat; (7) Rata-rata mahasiswa menyatakan bahwa belajar BI di UAD sangat meningkatkan minat 
mereka untuk dapat berbicara di luar lingkungan kelas atau di luar jam mata kuliah tersebut; (8) Ada mahasiswa yang mengusulkan agar dosen BI sering membawa mahasiswa untuk mengunjungi tempat-tempat yang ada turis asingnya, untuk praktik berbicara di bawah pengawasannya.

\section{PEMBAHASAN}

Berdasarkan berbagai cuplikan data dari keempat kategori tersebut di atas, penulis mencoba membahasnya per-unit satuan data atau kategori.

\section{Low-motivated with Low- achievement Category}

Kategori ini terdiri dari tiga subjek bermotivasi rendah, dengan hasil belajar rendah. Berdasarkan ekspresi mereka, tampak bahwa mereka benar-benar tidak suka BI karena tidak menyadari manfaatnya. Bisa dipastikan, mereka bukan hanya tidak suka belajar BI, namun juga belajar materi apapun, karena sebenarnya mereka tidak berniat kuliah. Logikanya, mahasiswa yang pintar tentu progresif dan tentu menyadari pentingnya belajar apa pun, termasuk BI.
Temuan ini tidak perlu dikembangkan karena sangat sulit mengembangkan orang yang tidak punya kesadaran belajar (selfawareness). Kenyataan tersebut sejalan dengan teori Gestalt (dalam Woolfolk, 1984) bahwa proses belajar memerlukan satu kesatuan aspek berpikir, mengingat, dan sadar diri. Seperti bentuk tubuh yang sistemik, masing-masing anggota sistem tidak bisa berdiri sendiri. Bila anggota tubuh terlcerai-berai, maka tubuh akan mati atau paling tidak, tidak berfungsi secara optimal. Demikian pula halnya dengan kesadaran seseorang dalam belajar.

\section{Well-motivated with Low- achievement Category}

Ada 10 informants yang
termasuk dalam kategori ini.
Berdasarkan ekspresi tertulis mereka,
dapat disimpulkan bahwa sebenarnya
mereka berminat belajar BI.
Daya serap dan hasil belajar mereka
yang rendah bukan disebabkan oleh
rendahnya minat belajar, mereka
namun karena keterbatasan
kemampuan awal yang kurang
menguntungkan. Kemampuan awal
yang kurang menguntungkan tersebut


ada yang disebabkan oleh faktor guru dan faktor manusiawi yang disebut

'lupa'.

Kedua faktor di atas membuat mereka sangat lamban dalam merespons stimulus dosen. Menurut konsep Behaviorisme, pengalaman belajar yang tidak menyenangkan akan mengimbas pada proses mendapatkan wawasan (insight) berikutnya (Bower, 1981: 17). Padahal, penguasaan BI merupakan proses pengkondisian atau pembiasaan yang mestinya tidak boleh terputus, karena bahasa adalah habit. Jika pengkondisian terputus,, konsekuensinya adalah mengulang kembali konsep/teori dari dasar untuk mengembalikan memori masa lalu yang tertumpuk oleh wawasan baru. Konsep pengulangan dalam penelitian ini dilakukan dengan cara memberikan materi yang berbobot kesulitan sama dengan materi BI di SMA. Namun demikian, untuk mengembalikan semangat dan meningkatkan prestasi kategori kelompok mahasiswa ini perlu didukung oleh ketersediaan waktu yang relatif panjang. Kendala upayanya adalah keterbatasan waktu yang tersedia sehingga hasilnya relatif belum optimal.

\section{Stabilized-progress with Stable-}

\section{achievement Category}

Kode unit data di atas memuat ekspresi mahasiswa yang motivasi dan hasil belajarnya stabil. Mereka sangat berminat belajar BI, bukan hanya di PT namun sejak mereka belajar di sekolah menengah. Mereka selalu memiliki pengalaman menyenangkan dalam belajar BI, sehingga mudah untuk mengembangkan kompetensi, mereka, baik secara mandiri maupun dengan bimbingan dosen. Mereka pun rata-rata memiliki hasil belajar yang relatif tinggi, yang ditunjukkan dari kumulatif hasil tes formatif, Midterm dan ujian akhir semester (UAS) mereka.

\section{Progressive-experience with}

\section{Significant-achievement Category}

Kelompok data inilah
yang paling dominan, paling
menarik dan mudah ditingkatkan
kualitas belajarnya, karena mereka


bermotivasi belajar tinggi. Mereka juga menyadari pentingnya penguasaan BI. Namun karena kurangnya sarana pendukung eksternal, seperti: rendahnya kualitas guru, tidak tersedianya laboratorium bahasa, alat serta materi pelajaran yang tidak memadai, dan sebagainya, membuat kelompok ini menjadi kurang bergairah belajar. Padahal, gairah belajar perlu untuk membangkitkan motivasi. Peserta didik semacam ini memerlukan dosen profesional. Dalam hal ini, dosen sudah mencoba melakukannya secara langsung. Buktinya adalah ekspresi mahasiswa K, L, M, dan $\mathrm{H}$, yang merasa senang dengan cara mengajar dosen BI yang ramah, humoris, sabar, kreatif, trampil membangkitkan semangat belajar, dan sering melibatkan mahasiswa untuk praktik berbicara. Berbagai sifat dosen tersebut masuk dalam kriteria guru berkualitas dan profesional menurut Gage dan Berliner (1984: 587).

Atas dasar temuan yang berkaitan dengan variabel profesionalisme dosen di atas,, dapat diinterpretasikan bahwa dugaan tentang rendahnya profesionalisme dosen BI adalah tidak terbukti sama sekali. Dengan kata lain, rendahnya kualitas penguasaan mahasiswa Prodi BK FIP UAD lebih didominasi oleh faktor-faktor berikut: (1) rendahnya intakes BI yang disebabkan oleh rendahnya kualitas guru BI di sekolah menengah, (2) motivasi belajar yang relatif rendah yang ditunjukkan oleh rendahnya etos belajar sebagian besar mahasiswa, dan (3) faktor 'lupa' yang menurut Klein (1996: 448) disebabkan oleh terjadinya penumpukan memori baru yang saling menginterferensi dalam formasi syaraf otak, dan kegagalan dalam menghadirkan berbagai ekspresi kebahasaan yang sebelumnya pernah dipelajari selama bertahun-tahun.

\section{Berdasarkan temuan-temuan} berikut analisisnya sebagaimana diuraikan di muka, dapat disimpulkan bahwa kesulitan belajar bahasa Inggris para mahasiswa program studi Pendidikan Ekonomi UMTS adalah variatif. Ragam penyebab kesulitan belajar mahasiswa adalah sebagai berikut: (1) Tidak ada minat belajar karena tidak suka belajar BI (2) Berminat belajar BI tetapi pengetahuan 
dasarnya kurang; (3) Motivasi baik, kemampuan baik, namun lingkungan kurang mendukung; (4) Motivasi cukup baik, tetapi 'lupa' konsep dasar yang pernah dipelajarinya; dan (5) Motivasi belajar tinggi, tetapi kesempatan belajar terlalu singkat. Berikut ini adalah penjelasan mengenai kelima kesimpulan kesulitan belajar tersebut.

Ragam pertama adalah hasil analisis kesulitan belajar, karena terpaksa. Sebagaimana diterangkan di muka bahwa subjek penelitian ini adalah para mahasiswa program studi Pendidikan Ekonomi. Di lingkungan Prodi tersebut, BI bukan jurusan mereka, tetapi wajib diikuti. Sebagian mahasiswa menganggap bahwa mata kuliah (MK) BI mengganggu pelaksanaan proses pembelajaran MK lain yang lebih relevan dengan jurusan mereka. Selain sulit, MK BI dianggap sebagai tambahan beban. Kemungkinan lain, tiga mahasiswa yang tergolong dalam kelompok ini memang mempunyai daya serap rendah. Biasanya, orang yang pintar akan menyukai BI atas dasar selfawareness akan arti pentingnya penguasaan BI bagi masa depan mereka.
Ragam kedua, kesulitan belajar disebabkan oleh kurangnya pemahaman konsep dasar BI, yang mestinya sudah pernah dipelajari selama kurang lebih 6 tahun di sekolah menengah. Dalam hal ini, mustahil bagi dosen BI untuk mengulang semua konsep pengetahuan dalam waktu yang amat singkat (2 SKS dan hanya satu semester). Solusinya adalah menambah waktu atau frekuensi belajar.

Ragam ketiga, kesulitan belajar karena lingkungan kurang mendukung. Artinya, peserta didik bermotivasi belajar baik dan cukup pintar namun tidak didukung oleh sarana prasarana pembelajaran yang memadai. Dengan demikian, kategori mahasiswa ini tidak dapat mencapai hasil belajar secara optimal. Optimalisasi hasil belajar pada kelompok mahasiswa ini adalah dengan mengkondisikan lingkungan belajar yang kondusif, guna peningkatan penguasaan kompetensi atau ketrampilan berbahasa Inggris. Dalam hal ini, penulis telah berusaha menciptakan kondisi tersebut dengan metode belajar kelompok. Adapun hasilnya dapat dilihat dari penampilan 
mereka saat diminta untuk berbicara di depan kelas, baik secara monolog maupun dialog.

\section{Ragam keempat, kesulitan}

belajar karena adanya faktor 'lupa'. Secara konseptual, belajar saat ini adalah kelanjutan perolehan pada masa-masa sebelumnya. Belajar bahasa termasuk BI merupakan suatu kebiasaan (habit) yang seharusnya dilakukan secara aktif dan intensif. Jika kegiatan sempat berhenti dalam waktu yang lama, faktor 'lupa' pasti terjadi. Namun faktor tersebut dapat dihilangkan dengan cara menggugah kembali memori yang tertimbun wawasan baru, dengan cara terus menerus melakukan latihan (intensive drilling). Pemberian latihan berbahasa secara intensif akan tidak ada masalah, jika niat belajar peserta didik tinggi. Solusinya adalah dengan mengefektifkan waktu belajar yang tersedia. Tetapi ada kendala untuk pelaksanaan solusi tersebut, yaitu jadwal mata kuliah yang menurut para mahasiswa terlampau pagi (Pukul 08.00). sulit diubah karena tempat belajar terbatas. Solusinya, kelas BI dapat dilakukan di luar kelas (outdoors' class).
Ragam kelima adalah kesulitan belajar karena kurangnya kesempatan, baik untuk belajar di kelas maupun untuk pengembangan penguasaan bahasa secara mandiri. Hal ini diketahui, dari keluhan sebagian besar mahasiswa yang merasa terbebani oleh adanya tugas- tugas mata kuliah lain yang terlalu banyak. Hal ini dapat dilihat pada saat mengecek pengerjaan tugas take home, yang sering tidak dikerjakan oleh banyak mahasiswa. Cara mengatasinya, dosen meminta mereka untuk mengerjakan tugas di kelas, kemudian langsung dibahas (untuk tugas pengembangan language functions) atau dipraktikkan (untuk pengembangan language skills). Dengan demikian mahasiswa merasa terkurangi bebannya dan dengan senang hati melalukannya. Hal ini dapat dilihat pada ekspresi mereka yang berkaitan dengan profesionalisme dosen BI mereka.

Atas dasar kesimpulan di atas, penulis menyarankan: (1) dosen dan lembaga hendaknya meningkatkan motivasi belajar BI melalui berbagai 
aktivitas pendukung praktik berbahasa dan pemberian rewards bagi mahasiswa yang rajin; (2) mendasari program pembelajaran dengan analisis kebutuhan atau yang lebih dikenal dengan ESP ( English for Special Purpose) ; (3) hendaknya dosen jeli dalam memilih metode yang sesuai dengan situasi, kondisi dan kebutuhan pembelajaran; (4) menambah kesempatan belajar; (5) pembelajaran difokuskan pada praktik menggunakan bahasa, bukan sekedar pembelajaran pola-pola bahasa.

\section{DAFTAR PUSTAKA}

Alisyahbana, S.T.A. (1994). The

Teaching of English in Indonesia. Oxford: Oxford University Press.

Cunningsworth, Alan. 1995.

Choosing Your Coursebook.

Great Britain: The Bath

Press.

Gage and Berliner. (1984). Educational Psychology. London: Houghton Mifflin Company.
Gall, Meredith D. \& Gall, Joyce P. 2003. Educational Research: An Introduction (Seventh Edition). Boston: Pearson Education, Inc.

Imam Barnadib. (1994). Citra Guru dan Layanan Profesionalnya (Makalah dalam Jurnal Penelitian IKIP). Yogyakarta: Lembaga Penelitian IKIP.

Klein, Stephen B. 1996. Learning Principles and Application.New York: McGraw-Hill, Inc.

McDonough, Jo \& McDonough, Steven. 1997. Research Methods for English Language Teachers. New York: St.Martin's Press, Inc.

Richards, Jack C. 2001. Curriculum and Materials Development for English Teaching. Cambridge: Cambridge University Press.

Soedijarto. (1993). Menuju Pendidikan yang Relevan. Jakarta: Balai Pustaka.

Stinnett, T.M. (1965). The Profession of Teaching. 
New Delhi: Prentice Hall of India (private) LTD.

Tomlinson, Brian. 1998. Materials Development in Language Teaching. $\quad$ Cambridge: Cambridge University Press.

Tomlinson, Brian. \& Masuhara, Hitomi. 2004. Developing Language Course Materials. Singapore: SEAMEO Regional Language Centre.

Woolfolk, Anita., et al. (1984). Educational Psychology for Teachers. New Jersey: Prentice- Hall Inc.

Yin, Robert K., 1987. Case Study Research Design and Methods.Beverly Hills, London: Sage Publication. 